\title{
RUNNING DETAILS ON THE TWO MOVEMENTS IN THE INTELLECTUAL HISTORY OF SCIENCE AND IDEAS
}

\author{
Raffaele Pisano \\ Lille 3 University, France
}

\begin{abstract}
A long tradition ${ }^{1}$ concerning the causes of the planetary movements existed as to the movements on the earth: the so called problem de motu locali. Starting from late middle Ages many criticisms were carried out against the Aristotelian doctrine of natural and violent motions. A well accredited and historically coherent theory to explain the movement and the change of movement was the medieval theory of impetus substantially developed by Jean Buridan (ca. 1300-ca. 1360) and by Nicolas d'Oresme (1320? 1325?-1382) on the basis of ideas that came back to John Philoponus (490-570).

The historical genesis of the theory of impetus - later applied to the motion of projectiles - is quite complex and varied. Aside from Aristotle's initial theory (384-322 B.C.), among the scholars who dealt with the topic, we note: Giovanni Filipono (active in VI century. B.C.), Pūr Sina` or commonly called in Latin Avicenna (980-1037), Roger Bacon (1214-c.1292/4), Tommaso D'Aquino (1225-1274), Pietro Giovanni Olivi (s.d.), Francesco di Marchia (s.d.), William of Ockham (ca. 1280-ca. 1349), and for some considerations, Jordanus de Nemore, too. Here, for the sake of brevity, and since there is already a vast literature on the topic, we refer only to that which historians consider to be a true cultural background of projectile theory until the Renaissance. That is, Buridan's theory, co-director of the Ecole de Paris which later replaced that of Chartres (15th century).

Niccolò Tartaglia (1499?-1557) also presented contributions to the art of warfare in Nova scientia (1537, Books I-II) and Quesiti et inventioni diverse (1554, Books I-III; see recently Pisano and Capecchi 2014, Springer). Tartaglia was not able to formulate a modern theory of projectiles through, e.g., a correct mathematical interpretation (nowadays) of a parabolic trajectory. In effect, the path was curve but not parabolic. We know that Galileo would only be able to do this (finally calculus and graphs) around 1609 . This involves a case-study on the trajectory of projectiles which Tartaglia had not yet sufficiently developed from a theoretical point of view. Briefly, because it is not our intention to discuss impetus in detail since there is already a vast, definitive literature on the subject. We only refer to that which historians consider a true cultural background of projectile theory until the Renaissance; that is, Buridan's (ca. 1300-ca. 1360) medieval theory (1509):
\end{abstract}

- The impetus varies with the speed of the projectile and with its mass. Paraphrasing Buridan, we can say, more speed impressed by the motor on the mobile, stronger the transmitted impetus.

- The impetus is a permanent quality different and distinct from the motion and the mass of the projectile. A characteristic of permanence of the impetus might be weakened by the movement, i.e., by the air resistance and the degree of inclination of the launch.

Nicolas d'Oresme's version should also be considered (see Clagett's literature, 1959) and in turn reproduced by Maier (1968) which, in turn, includes - with some modifications - the Parisian edition from 1509. For the com-

1 The argument of this editorial concerns a current research in progress (since 2013) by Paolo Bussotti and me (Cfr.: Pisano and Bussotti 2017, forthcoming; see also: Pisano and Bussotti 2014; Pisano and Capecchi 2013). 
ments of Subtilissimae Quaestiones, at first glance, one can see Clagett). Clagett dated Buridan's manuscript around 1357. It is archived at the Vatican Library in Roma (Vat. Lat. 2136, 1r.).

Buridan also attempted a mathematical reasoning of the impetus without, however, producing any formal language. It is quite probable that before 1607, Galileo had not yet clarified the theory on the composition of vertical and horizontal motion. This non-clarification was mostly likely due to a lack of sufficient experimental proofs and the known caution with which Galileo avoided affirmations devoid of sensate esperienze; this was the case until he wrote his notes in the famous code Ms. 72, precisely in folio 116v (1608, Galileo Ms. 72, 116v) in which he outlined the solution. It should be noted that in Galileo's time, typically Aristotelian motion was supported by the dichotomy of violent and natural motion. But what about reasoning on the violent and natural causes connected with concept of gravity? The discourse by Plutarch De facie quae in orbe Lunae apparet looks, despite its metaphoric style, an important contribution in this sense. Kepler translated this work by Plutarch (Kepler, KGW, 11) from Greek into Latin and Kepler criticized explicitly the Aristotelian theory of natural places more than once.

Finally the problem de motu locali was connected - using modern terms - with gravity. If, as Aristotle did, one supposes that the bodies are naturally heavy or light, this is not a great problem, but as soon as this conviction begins to vacillate, the question how and if the bodies mutually attract become fundamental to understand the movements of the bodies themselves. Likely, even in the Hellenistic period there were criticisms to Aristotelian doctrine of natural places.

\section{References}

Buridan, J., (1509). Subtilissimae Quaestiones super octo Physicorum libros Aristotelis. Paris [Reprint: (1964), Kommentar zur Aristotelischen Physik [Commentary on Aristotelian physics]. Frankfurt: Minerva].

KGW-Kepler Gesammelte Werke [KGW-Kepler collective works] (1937-2009). Deutsche Forschungsgemeineschaft and Bayerische Akademie der Wissenschaften. Van Dyck W, Caspar M. (eds). München: Beck'sche Verlagsbuchandlung.

Pisano, R., Bussotti, P. (2014). Historical and philosophical reflections on the culture of machines around the renaissance. How science and technique work? Acta Baltica Historiae et Philosophiae Scientiarum, 2 (2), 20-42.

Pisano, R., Bussotti, P. (2017). On the conceptualization of force in Johannes Kepler's Corpus: an interplay between physics, mathematics and metaphysics. In: Pisano, R., Agassi, J., Drozdova, D., (Eds). Hypotheses and perspectives in the history and philosophy of science homage to Alexandre Koyré 1964-2014. Dordrecht: Springer, forthcoming.

Pisano, R., Capecchi, D. (2013). Conceptual and mathematical structures of mechanical science in the Western Civilization around 18th century. Almagest, 4 (2), 86-121.

Pisano, R., Capecchi, D. (2014). Tartaglia's science weights. Mechanics in sixtheen century. Selection from Quesiti et invention diverse: Books VII-VIII. Dordrecht: Springer.

Tartaglia, N. (1537). La noua scientia de Nicolo Tartaglia: con una gionta al terzo libro. [Tartaglia's new science]. Venetia: Stephano Da Sabio.

Tartaglia, N. (1554). La nuova edizione dell'opera Quesiti et inventioni diverse de Nicolo Tartaglia brisciano [Tartaglia's quesiti]. Riproduzione (1959) in facsimile dell'edizione del 1554 by Arnaldo Masotti. Commentari dell'Ateneo di Brescia. Brescia: Tipografia. La Nuova cartografica. 